\title{
EXPERIENCE STUDENT BACKGROUND AND THEIR BEHAVIOR IN PROBLEM SOLVING
}

\author{
Yulyanti Harisman $^{* 1}$, Muchamad Subali Noto ${ }^{2}$, Wahyu Hidayat ${ }^{3}$ \\ ${ }^{1}$ Universitas Negeri Padang \\ ${ }^{2}$ Universitas Swadaya Gunung Djati \\ ${ }^{3}$ Institut Keguruan dan Ilmu Pendidikan Siliwangi
}

\begin{tabular}{l}
\hline Article Info \\
\hline Article history: \\
Received Jan 14, 2020 \\
Revised Feb 11, 2020 \\
Accepted Feb 18, 2020
\end{tabular}

Keywords:

Behaviors,

Experience Student,

Problem Solving

\begin{abstract}
These Students' mathematical problem solving behavior had been presented in the previous paper. Four categories of students' mathematical problem solving behavior in junior high schools in Indonesia had been obtained. These categories were: naive, routine, semi-sophisticated, and sophisticated. This paper was a continuation of that research. In this session would discuss about external aspects affect student behavior in problem solving. This research used survey method. Eighteen students from three junior high schools in Indonesia had been interviewed about it. These three aspects were: distance of home from school, family background, Contests - contests like math Olympiads that had been followed. The interview results were coded to get conclusions. Research findings were that the external aspects of students did not influence students in behaving to solve problems in mathematics. the implication of this finding is that the main factor influencing student behavior in problem solving is teacher professionalism in learning not from the students themselves, so the teacher must be really prepared in designing all components of learning well.
\end{abstract}

Copyright $(2020$ IKIP Siliwangi. All rights reserved.

\section{Corresponding Author:}

Yulyanti Harisman,

Department of Mathematics Education,

Universitas Negeri Padang,

Jl. Prof. Dr. Hamka, Air Tawar, Padang City, West Sumatera, Indonesia.

Email: yulyanti_h@fmipa.unp.ac.id

\section{How to Cite:}

Harisman, Y., Noto, M. S., \& Hidayat, W. (2020). Experience student background and their behavior in problem solving. Infinity, 9(1), 59-68.

\section{INTRODUCTION}

Mathematical problem solving is core of mathematics learning. Problem solving occupies a central position and is one of the most important forms of learning in mathematics (Napitupulu, 2008). Schoenfeld (1980) confirms that the problem solving process is one of the most important aspects of mathematics that must get attention from the teacher. In various curriculums, problem solving is central in mathematics learning. State that Ho \& Hedberg (2005) mathematical problem solving (MPS) as the central focus in the primary mathematics syllabus for all Singapore schools. Furthermore, Pratiwi, Masfuah, \& Rondli (2018) state that 21st century skills and competencies according to UNESCO include critical thinking and problem solving (solving problems), communication and collaboration, social and cross-cultural skills, and information literacy. 
Problem solving will make students be creative and critical both in learning and in life. According to Andersson (2007) mathematical problem solving will trigger the memory of children for working.

Such research on problem solving has significant implications. Some researchers developed more direct instructional approaches that were designed to help students acquire schemata to solve mathematics problem solving (Hidayat \& Sariningsih, 2018; Nunokawa, 2005). Goos \& Galbraith (1996) in her research implement the nature of secondary students' metacognitive strategy use, and how these strategies are applied when students work together on problems. The findings of that research is shed some light on the nature of individual and interactive metacognitive strategy use during collaborative activity. Yerushalmy (2000) in his research describes a longitudinal observation of a pair of students that studied algebra for 3 years using a function approach, including intensive use of graphing technology. In his study is an attempt to analyze students construction of function based problem solving methods in introductory algebra. His study also offers terms for describing and explaining what and how do learners appreciate and make out of solving introductory school algebra problems over a three years course. Puteh \& Ibrahim (2010) does research on the self-regulated learning strategies among form four students in the State of Perak, Malaysia. She did a case study to determine the usage of self-regulated strategies among the students and how it helps the students in solving mathematics' problems. Puteh \& Ibrahim (2010) research revealed the level of motivation and the existence of self-regulated learning strategies among the students. This research also has shown that there is a strong relationship between the self-regulated learning strategies and the students' performance of problem solving. Furthermore, Funke (2013) identified the effects of different strategies on the problem-solving performance of junior high school algebra students. The finding of his research is the efficiency of these strategies depended on the number of steps in the problem solution, the number of possible blind alleys, and memory load requirements.

Research about how student solve the problem is also important beside the implementation of the strategy by teacher in learning about problem solving. Some researchers have done it. Harisman, Noto, Bakar, \& Amam (2017) and Harun et al. (2018) in their research had seen how the gesture of student with different gender and different behavior when they solve the problem. The finding of her research is there is different gesture between male student and female student when they solve problem that given. Futhermore, Schoenfeld (1982) did the research about how the behavior student in solve problem. The finding of Schoenfeld research there was two behaviors of student in solve problem he gave name with expert and novice problem solver. The expert of problem solving tend to recognize the patterns of problems, tend to change strategy when a strategy is not working, and an expert of problem solving can generate its own strategy in solving problems. Some of the behavior displayed by novice problem solvers in solving the problem are: only recognize the problem of the surface of it, tend to just manipulating numbers in solving problems, and unable to move strategy if a strategy does not work. This research was continued by Muir, Beswick, \& Williamson (2008), the research findings of Muir et al. (2008) complemented the research done by Schoenfeld. If Schoenfeld categorized the behavior of students when solving problems in two categories namely expert and novice, then Muir categorized it into three categories: naive, routine, and sophisticated. Naive behavior oriented on problem solver behavior associated only with manipulating numbers that exist in the problem. Routine behavior oriented on structured behavior and sophisticated problem solvers oriented on problem solver who can generate their own strategies when they were faced with problems. Harisman, Kusumah, \& 
Kusnandi (2018) found four category of problem solving student behaviour that gave named: Apathetic, routine, semi-sophisticate, and sophisticated.

This research is a continuation of Harisman's research (Harisman et al., 2018) which focuses on what factors influence students' behavior in problem solving. There are two factors that influence student behavior in problem solving, namely internal factors and external factors. External factors include the teacher who teaches about problem solving and the teks book that used. This has been studied in Harisman's research, the finding of this research is teacher beliefs, reflection, didaktik and pedagogi, attitude of teacher and the teks books that used will influent student behavior in problem solving. The research that has been carried out leaves the question of how the factors of the students themselves are like the distance of the homes of students from schools, families and so on. This paper was trying to answer that question. This series of investigations extends earlier work to include the examination of how distance of student home from school, family background of student, Contests - contests like math Olympiads that had been followed might influence problem solving behavior of student (Harisman et al., 2018; Harisman, Kusumah, \& Kusnandi, 2019a; 2019b; Harisman, Kusumah, Kusnandi, \& Noto, 2019; Kariman, Harisman, Sovia, \& Prahmana, 2019).

\section{METHOD}

This research was survey method. Eighteen students from three different junior high school with different cluster were chosen as research subject. From each school had chosen six student with different ability (low, middle, and high ability) about mathematic achievement. The students were recommended by school teachers based on mathematical ability. Students were labeled T to high-ability students, $\mathrm{S}$ for medium students, and $\mathrm{R}$ for lower-ability students. Furthermore, in labeling schools, S-1 is for the school one, S-2 for the school two, and S-3 is for school three. Each student had been classified into four behavior in problem solving at Harisman et al. (2018) that categories gave named: Apathetic, routine, semi-sophisticate, and sophisticated. The following explanation is in the Table 1 names and abilities of students in each school.

Table 1. Name and ability of students at each school

\begin{tabular}{cccc}
\hline No & Students at the school one & Students at the school two & Students at the school three \\
\hline 1 & Lutfi (R) S-1 & Dwi Nanda (R) S-2 & Fauzan (R) S-3 \\
2 & Divy (R) S-1 & Aulia Fauza (R) S-2 & Rizky (R) S-3 \\
3 & Fikri (S) S-1 & Najla (S) S-2 & Mesya(S) S-3 \\
4 & Dhea (S) S-1 & Febrina (S) S-2 & Dita (S) S-3 \\
5 & Annisa (T) S-1 & Zara (T) S-2 & Yani (T) S-3 \\
6 & Alvaro (T) S-1 & Salma (T) S-2 & Nadhira (T) S-3 \\
\hline
\end{tabular}

Each student had been classified into four behavior in problem solving at Harisman et al. (2018) that categories gave named: Apathetic, routine, semi-sophisticate, and sophisticated. It can be seen in following Table 2. 
Table 2. Recapitulation of each students' behavior

\begin{tabular}{ccccc}
\hline No & Apathetic & Routine & semi-sophisticate & sophisticated \\
\hline 1 & Lutfi (R) S1 & Dhea (S) S1 & Annisa (T) S1 & Alvaro (T) S1 \\
2 & Fikri (S) S1 & Najla (S) S2 & Zara (T) S2 & Nadhira (T) S3 \\
3 & Divy (R) S1 & Febrina (S) S2 & Salma (T) S2 & \\
4 & Mesya(S) S3 & Dwi Nanda (R) S2 & Yani (T) S3 & \\
5 & Dita (S) S3 & Aulia Fauza (R) S2 & & \\
6 & Fauzan (R) S3 & & & \\
7 & Rizky (R) S3 & & & \\
\hline
\end{tabular}

Each rubric in the category of mathematical problem solving behavior in Harisman et al. (2018) research can be seen as Table 3.

Table 3. A picture of student behavior based on the range of student behavior

\begin{tabular}{|c|c|c|c|c|c|c|}
\hline \multirow[b]{2}{*}{ No } & \multirow[b]{2}{*}{ Factor } & \multirow[b]{2}{*}{ Indicator } & \multicolumn{4}{|c|}{ Category Of Behavior } \\
\hline & & & Apathetic & Routine & $\begin{array}{c}\text { Semi } \\
\text { Sophisticated }\end{array}$ & Sophisticated \\
\hline \multirow[t]{3}{*}{1} & $\begin{array}{l}\text { Knowledge } \\
\text { Ownership }\end{array}$ & $\begin{array}{l}\text { The application of } \\
\text { Polya's heuristic } \\
\text { steps in } \\
\text { mathematical } \\
\text { problem solving }\end{array}$ & $\begin{array}{l}\text { Made a mistake } \\
\text { on the four } \\
\text { solving steps }\end{array}$ & $\begin{array}{l}\text { No effort to } \\
\text { verify the } \\
\text { solution (Make a } \\
\text { mistake on some } \\
\text { troubleshooting } \\
\text { steps) }\end{array}$ & $\begin{array}{l}\text { There is an } \\
\text { attempt at } \\
\text { verifying the } \\
\text { solution but still } \\
\text { making mistakes } \\
\text { on some } \\
\text { troubleshooting } \\
\text { steps }\end{array}$ & $\begin{array}{l}\text { A high score on } \\
\text { each } \\
\text { troubleshooting } \\
\text { step }\end{array}$ \\
\hline & & $\begin{array}{l}\text { The use of prior } \\
\text { knowledge for } \\
\text { mathematical } \\
\text { problem solving }\end{array}$ & $\begin{array}{l}\text { Cannot use } \\
\text { previously } \\
\text { resolved issues }\end{array}$ & $\begin{array}{l}\text { Can identify a } \\
\text { similar problem, } \\
\text { but not on the } \\
\text { mathematical } \\
\text { structure (can } \\
\text { identify similar } \\
\text { problems only } \\
\text { on external } \\
\text { features only) }\end{array}$ & $\begin{array}{l}\text { Can identify a } \\
\text { similar problem, } \\
\text { but not on the } \\
\text { mathematical } \\
\text { structure, but can } \\
\text { be directed to look } \\
\text { at problems in the } \\
\text { mathematical } \\
\text { structure }\end{array}$ & $\begin{array}{l}\text { Identify similar } \\
\text { problems } \\
\text { according to the } \\
\text { mathematical } \\
\text { structure } \\
\text { his }\end{array}$ \\
\hline & & $\begin{array}{l}\text { Many ways are } \\
\text { used in } \\
\text { mathematical } \\
\text { problem solving }\end{array}$ & $\begin{array}{l}\text { Often use the } \\
\text { same way to } \\
\text { solve all } \\
\text { problems } \\
\text { because of the } \\
\text { limitations of } \\
\text { knowledge } \\
\text { possessed }\end{array}$ & $\begin{array}{l}\text { Focus on one } \\
\text { way with the } \\
\text { knowledge you } \\
\text { have to solve a } \\
\text { particular } \\
\text { problem, but } \\
\text { have no desire to } \\
\text { generate the } \\
\text { right way to } \\
\text { solve the }\end{array}$ & $\begin{array}{l}\text { Focus on one way } \\
\text { with the } \\
\text { knowledge you } \\
\text { have to solve a } \\
\text { particular } \\
\text { problem, but have } \\
\text { a desire to } \\
\text { generate the right } \\
\text { way to solve the } \\
\text { problem }\end{array}$ & $\begin{array}{l}\text { Identify other } \\
\text { ways of } \\
\text { troubleshooting }\end{array}$ \\
\hline
\end{tabular}




\begin{tabular}{llllll}
\hline & & & \multicolumn{3}{c}{ Category Of Behavior } \\
\cline { 3 - 5 } No Factor & Indicator & Apathetic & Routine & $\begin{array}{c}\text { Semi } \\
\text { Sophisticated }\end{array}$ & Sophisticated \\
\cline { 3 - 6 } & & & problem &
\end{tabular}

$\begin{array}{ll}\text { Written and verbal } & \text { Written and } \\ \text { communication in } & \text { verbal } \\ \text { mathematical } & \text { communication } \\ \text { problem solving } & \text { is inadequate }\end{array}$

2 Self Control Thinking (Control) metacognition in mathematical problem solving communication

3 Confidence

4 Affective
Confidence in how to implement strategy in problem solving

Confidence in the variety of strategies used in mathematical problem solving strategy
Written communication is not clear, but can clarify through verbal communication
Written

communication is not clear, but can

clarify through

verbal

communication

and can be

directed to clarify

his written

communication

Metacognition

does not appear

in writing, but

metacognition appears verbally

Metacognition is not without writing, but metacognition appears verbally
Thinking metacognition is invisible, both in written and verbal and can be directed to perform metacognition processes in written answers

Doing exactly

the same strategy

Rely on one strategy 
In this research would focus on factors of the students themselves are like distance of student home from school, family background of student, contests - contests like math Olympiads that had been followed. Each student would give the open questions about it, and all of the answer would be video. The video results will be coded and analyzed using grounded theory which will be clearly specified.

\section{RESULTS AND DISCUSSION}

This section would detail the results of the video code transcript. Each type of student behavior would be corresponded with indicator of eksternal factor. The recapitulation of apathetic students' behavior with indicator eksternal factor can be seen in Table 4.

Table 4. Recapitulation of apathetic students' behavior with eksternal indicator factor

\begin{tabular}{ccccc}
\hline No & Apathetic & $\begin{array}{c}\text { Distance of } \\
\text { student home } \\
\text { from school }\end{array}$ & $\begin{array}{c}\text { Family } \\
\text { background }\end{array}$ & $\begin{array}{c}\text { Contests - contests like } \\
\text { math Olympiads that } \\
\text { had been followed }\end{array}$ \\
\hline 1 & Lutfi (R) S1 & Far from school & Rich family & Never followed \\
2 & Fikri (S) S1 & Far from school & Rich family & Never followed \\
3 & Divy (R) S1 & Far from school & Simple family & Never followed \\
4 & Mesya(S) S3 & Near from school & Poor families & Never followed \\
5 & Dita (S) S3 & Near from school & Poor families & Never followed \\
6 & Fauzan (R) S3 & Near from school & Poor families & Never followed \\
7 & Rizky (R) S3 & Near from school & Poor families & Never followed \\
\hline
\end{tabular}

The recapitulation of routine students' behavior with indicator eksternal factor can be seen in Table 5 .

Table 5. Recapitulation of routine students' behavior with eksternal indicator factor

\begin{tabular}{ccccc}
\hline No & Routine & $\begin{array}{c}\text { distance of } \\
\text { student home } \\
\text { from school }\end{array}$ & $\begin{array}{c}\text { family } \\
\text { background }\end{array}$ & $\begin{array}{c}\text { contests - contests like } \\
\text { math Olympiads that } \\
\text { had been followed }\end{array}$ \\
\hline 1 & Dhea (S) S1 & Near from school & Simple family & Never followed \\
2 & Najla (S) S2 & Far from school & Simple family & Never followed \\
3 & Febrina (S) S2 & Far from school & Simple family & Never followed \\
4 & Dwi Nanda (R) S2 & Near from school & Simple family & Never followed \\
5 & Aulia Fauza (R) S2 & Near from school & Simple family & Never followed \\
\hline
\end{tabular}

The recapitulation of Semi Sophisticated students' behavior with indicator eksternal factor can be seen in Table 6.

Table 6. Recapitulation of semi sophisticated students' behavior with eksternal indicator factor

\begin{tabular}{ccccc}
\hline No & $\begin{array}{c}\text { Semi } \\
\text { Sophisticated }\end{array}$ & $\begin{array}{c}\text { distance of } \\
\text { student home } \\
\text { from school }\end{array}$ & $\begin{array}{c}\text { family } \\
\text { background }\end{array}$ & $\begin{array}{c}\text { contests - contests like } \\
\text { math Olympiads that } \\
\text { had been followed }\end{array}$ \\
\hline 1 & Annisa (T) S1 & Near from school & Simple family & Never followed \\
2 & Zara (T) S2 & Far from school & Rich family & Never followed
\end{tabular}




\begin{tabular}{ccccc}
\hline No & $\begin{array}{c}\text { Semi } \\
\text { Sophisticated }\end{array}$ & $\begin{array}{c}\text { distance of } \\
\text { student home } \\
\text { from school }\end{array}$ & $\begin{array}{c}\text { family } \\
\text { background }\end{array}$ & $\begin{array}{c}\text { contests - contests like } \\
\text { math Olympiads that } \\
\text { had been followed }\end{array}$ \\
\hline 3 & Salma (T) S2 & Far from school & Simple family & Never followed \\
4 & Yani (T) S3 & Near from school & Simple family & Never followed \\
\hline
\end{tabular}

The recapitulation of Sophisticated students' behavior with indicator eksternal factor can be seen in Table 7.

Table 7. Recapitulation of sophisticated students' behavior with eksternal indicator factor

\begin{tabular}{ccccc} 
No & Sophisticated & $\begin{array}{c}\text { distance of student } \\
\text { home from school }\end{array}$ & $\begin{array}{c}\text { family } \\
\text { background }\end{array}$ & $\begin{array}{c}\text { contests - contests like } \\
\text { math Olympiads that } \\
\text { had been followed }\end{array}$ \\
\hline 1 & Alvaro (T) S1 & Near from school & Simple family & Ever followed \\
2 & Nadhira (T) S3 & Near from school & Simple family & Never followed \\
\hline
\end{tabular}

Based on the result of research, distance of student home from school, family background and contests- contests like math Olympiads that had been followed didn't influent behavior of student in problem solving. The findings of this study contradict with the findings of the study that did by Choy (2001). According Choy (2001) Family background would influent the achievement of the children. In her research Choy gave information on how student and family background characteristics and students high school experiences are related to their access to postsecondary education immediately after high school. Fuligni (1997) research is also in line with Choy (2001). He did his research in Latino, East Asian, Filipino, and European Adolescent to determine relative impact of family background, peer suport on academic achievement of student. The finding of his research there was a more significant correlations between family background and academic achievement of student. Base on Fehrmann, Keith, \& Reimers (1987) Parental involvement is considered an important influence on academic progress. Time spent on homework and in leisure TV viewing has an important effect on academic learning. Many cases about family background had not been covered in this study. We should find the specific thing that could influent student behavior in problem solving. so is the case with social culture, the environment, student activities and so on.

\section{CONCLUSION}

Research results show distance of student home from school, family background and contests-contests like math Olympiads that had been followed didn't influent behavior of student in problem solving. Further research is needed to examine more in terms of what affects students behaving in problem solving.

\section{REFERENCES}

Andersson, U. (2007). The contribution of working memory to children's mathematical word problem solving. Applied Cognitive Psychology: The Official Journal of the Society for Applied Research in Memory and Cognition, 21(9), 1201-1216. https://doi.org/10.1002/acp.1317 
Choy, S. P. (2001). Students whose parents did not go to college: Postsecondary access, persistence, and attainment. Essay in The Condition of Education

Fehrmann, P. G., Keith, T. Z., \& Reimers, T. M. (1987). Home influence on school learning: Direct and indirect effects of parental involvement on high school grades. The Journal of Educational Research, 80(6), 330-337. https://doi.org/10.1080/00220671.1987.10885778

Fuligni, A. J. (1997). The academic achievement of adolescents from immigrant families: The role of family background, attitudes, and behavior. Child development, 68(2), 351-363. https://doi.org/10.1111/j.1467-8624.1997.tb01944.x

Funke, J. (2013). Human problem solving in 2012. The Journal of Problem Solving, 6(1), 3. http://doi.org/10.7771/1932-6246.1156

Goos, M., \& Galbraith, P. (1996). Do it this way! Metacognitive strategies in collaborative mathematical problem solving. Educational studies in mathematics, 30(3), 229-260. https://doi.org/10.1007/BF00304567

Harisman, Y., Kusumah, Y. S., \& Kusnandi, K. (2018). Teachers' reflections on students' mathematical problem solving in junior high school. In Journal of Physics: Conference Series, 1088(1), 012011. http://doi.org/10.1088/17426596/1088/1/012011

Harisman, Y., Kusumah, Y. S., \& Kusnandi, K. (2019a). Beliefs of junior high school teachers on learning process on mathematical problem solving. In Journal of Physics: Conference Series, 1157(3), 032112. http://doi.org/10.1088/17426596/1157/3/032112

Harisman, Y., Kusumah, Y. S., \& Kusnandi, K. (2019b). How teacher professionalism influences student behaviour in mathematical problem-solving process. In Journal of Physics: Conference Series, 1188(1), 012080. http://doi.org//10.1088/17426596/1188/1/012080

Harisman, Y., Kusumah, Y. S., Kusnandi, K., \& Noto, M. S. (2019). The teachers'experience background and their profesionalism. Infinity Journal, 8(2), 129-142. https://doi.org/10.22460/infinity.v8i2.p129-142

Harisman, Y., Noto, M. S., Bakar, M. T., \& Amam, A. (2017). The different patterns of gesture between genders in mathematical problem solving of geometry. In Journal of Physics: Conference Series, 812(1), 012039. http://doi.org/10.1088/17426596/812/1/012039

Harun, L., Darhim, D., Dahlan, J. A., Harisman, Y., Sovia, A., \& Bakar, M. T. (2019). Students' gesture of naive, routine, and shopisticated behavior oriented on mathematical problem solving. In Journal of Physics: Conference Series, 1157(4), 042074. http://doi.org/10.1088/1742-6596/1157/4/042074

Hidayat, W., \& Sariningsih, R. (2018). Kemampuan pemecahan masalah matematis dan adversity quotient siswa SMP melalui pembelajaran open ended. JNPM (Jurnal Nasional Pendidikan Matematika), $\quad 2(1), \quad$ 109-118. http://dx.doi.org/10.33603/jnpm.v2i1.1027

Ho, K. F., \& Hedberg, J. G. (2005). Teachers' pedagogies and their impact on students' mathematical problem solving. The Journal of Mathematical Behavior, 24(3-4), 238-252. https://doi.org/10.1016/j.jmathb.2005.09.006 
Kariman, D., Harisman, Y., Sovia, A., \& Prahmana, R. C. I. (2019). Effectiveness of Guided Discovery-Based Module: A Case Study in Padang City, Indonesia. Journal $\begin{array}{llll}\text { on } \quad \text { Mathematics } & \text { 230(2), }\end{array}$ https://doi.org/10.22342/jme.10.2.6610.239-250

Muir, T., Beswick, K., \& Williamson, J. (2008). "I'm not very good at solving problems": An exploration of students' problem solving behaviours. The Journal of Mathematical Behavior, $27(3)$ 228-241. https://doi.org/10.1016/j.jmathb.2008.04.003

Napitupulu, E. E. (2008). Mengembangkan strategi dan kemampuan siswa memecahkan masalah matematik. Pythagoras: Jurnal Pendidikan Matematika, 4(2), 26-36.

Nunokawa, K. (2005). Mathematical problem solving and learning mathematics: What we expect students to obtain. The Journal of Mathematical Behavior, 24(3-4), 325-340. https://doi.org/10.1016/j.jmathb.2005.09.002

Pratiwi, I. A., Masfuah, S., \& Rondli, W. S. (2018). Pendidikan Multikultural Berbantuan Metode Pictorial Riddle Untuk Meningkatkan Karakter Kreatif dan Bersahabat Siswa Kelas 3 Sekolah Dasar. Scholaria: Jurnal Pendidikan Dan Kebudayaan, 8(2), 109-119. https://doi.org/10.24246/j.js.2018.v8.i2.p109-119

Puteh, M., \& Ibrahim, M. (2010). The usage of self-regulated learning strategies among form four students in the Mathematical problem-solving context: A case study. Procedia-Social and Behavioral Sciences, 8, 446-452. https://doi.org/10.1016/j.sbspro.2010.12.061

Schoenfeld, A. H. (1980). Heuristics in the classroom. Problem solving in school mathematics, 9-22.

Schoenfeld, A. H. (1982). Expert and Novice Mathematical Problem Solving. Final Project Report and Appendices BH.

Yerushalmy, M. (2000). Problem solving strategies and mathematical resources: A longitudinal view on problem solving in a function based approach to algebra. Educational studies in mathematics, 43(2), 125-147. https://doi.org/10.1023/A:1017566031373 
